\title{
Study on the Time Frame for Ossification of the Medial Clavicular Epiphyseal Cartilage by X-ray in Ghanaian Students
}

\author{
Estudio con Rayos $X$ sobre el Periodo de Tiempo para la Osificación \\ del Cartílago Epifisial Clavicular Medial en Estudiantes Ghaneses
}

Brown A. A.*; Derkyi-Kwarteng L." \& Amonoo-Kuofi H. S.***

BROWN A. A.; DERKYI-KWARTENG L. \& AMONOO-KUOFI H. S. Study on the time frame for ossification of the medial clavicular epiphyseal cartilage by X-ray in Ghanaian students. Int. J. Morphol., 31(2):491-496, 2013.

SUMMARY: The objective of this study was to determine the rate of ossification of the medial epiphysis of the clavicle and some of the different factors that may influence the rate of ossification in the Ghanaian population. The study was a retrospective study and was conducted at the University of Cape Coast hospital, Cape Coast, Ghana. Chest x-rays of 1035 first year University of Cape Coast students admitted, for the 2008/2009 academic year were used. Statistically significant differences were produced for some of the stages when sex comparisons were done using the t-test for two independent groups with a 95\% confidence level. Stages 2 ( $\mathrm{p}=0.001$ ), stage 3 $(\mathrm{p}<0.001)$ and stage $4(\mathrm{p}=0-001)$. The age of onset of ossification of the medial clavicle appeared generally to be earlier in females than in males. The stage of partial ossification of the medial clavicular epiphysis also lasted longer than in other studies indicating a delay in the ossification at this stage. In conclusion conventional x-ray of the medial clavicle can be an effective tool in assessing forensic age of subjects for any purpose; however there is a need to develop reference values that are specific for particular geographical areas.

KEY WORDS: Clavicle; Anatomy; Ossification.

\section{INTRODUCTION}

For close to over a hundred years the development and fusion of the medial epiphysis of the clavicle has been studied by different investigators. These studies have utilised both radiological assessment (Flecker, 1933; Jit \& Kullkarni, 1976; Kreitner et al., 1998; Schmeling et al., 2004) and direct skeletal observation (Todd \& D'Errico, 1928, McKern \& Stewart, 1957; Webb \& Suchey, 1985; Ji et al., 1994; Black $\&$ Scheuer, 1996) and have shown that the stages of development and the eventual fusion with the clavicular shaft can be used in the identification of the forensic age of the living or the dead (McKern \& Stewart, 1957; Webb \& Suchey, 1985).

The need to estimate the age of living subjects has become important especially in the area of criminal law and in age limited sporting events. In criminal cases forensic age estimation can be used to ascertain whether the defendant's stated age matches his or her chronological age. The radiographic method of assessing ossification is a reliable tool in estimation of the age of the living subject. Studies have shown that plain $\mathrm{x}$-rays can be used to assess the stage of ossification of the medial clavicular epiphysis and hence age estimation (Schemling et al. 2004), especially when used in addition to an X-ray of the left hand and dental examination. (Schmeling et al., 2001).

Published work in this area, involved subjects of different ethnic origins and geographical location. Todd and D'Errico (1928) examined black Americans in the United States; Jit \& Kulkarni(1976) studied Northern Indians; Webb \& Suchey (1985) sampled white and black US populations and Latin Americans while Ji et al. (1994) studied Asians. There appears to be some doubt as to whether figures from one geographical area are applicable to other areas although ethnicity has been found not to exert much influence on the rate of ossification individuals of similar age (Schmeling et al., 2000; Meijerman et al., 2007).

Socio-economic status of a subject may however have a significant influence on the rate of ossification of the medial clavicular epiphysis (Schmeling et al., 2006 and Meijerman et al., 2007). Individuals of relatively high socio-economic status tend to have a faster rate of ossification than people of lower socio-economic status therefore if reference values

\footnotetext{
* B.sc.,MBChB. Lecturer Department of Anatomy, School of Medical Sciences, University of Cape Coast, Ghana.

${ }^{* *}$ Dip Ed., MBChB, Ph.D. Professor Department of Anatomy, School of Medical Sciences, University of Cape Coast, Ghana.
} 
drawn from studies with socio-economically advanced populations were to be applied to subjects from low socioeconomic populations, it could result in erroneous interpretation.

There appear to be no published reports of studies of the medial epiphysis of the clavicle in Ghanaian populations. The present study was undertaken to determine the rate of ossification of the medial epiphysis of the clavicle in the Ghanaian population.

\section{MATERIAL AND METHOD}

Chest x-rays of 1035 students were studied. These were taken at the University of Cape Coast hospital as part of the medical examination of newly admitted students for the 2008/2009 academic year. The ages of the subjects ranged between 16 and 32 years. Selection was based on accurate information on date of birth and subjects were certified to be in good health by medical examination.

Assessment of the degree of ossification of the medial clavicular epiphysis was difficult in 82 chest $\mathrm{x}$-rays on both sides due to superimposition of surrounding structures, this represents about $7.9 \%$ of the sample. X-rays of students who were shown to have no nutritional deficiency based on their physical examination results were selected while $\mathrm{x}$-rays from students who had bone diseases or history of shoulder injury or surgery were excluded.

All x-ray images were taken using Philips, BuckyDiagnost, Germany. Images were scanned using Kodak point-of-care CR140 system and viewed using Kodak Acquisation software. Results are expressed as minimum, maximum and mean \pm standard deviation. Differences between interesting groups were compared by t-test for two independent groups with a 95\% confidence level. All data was analysed using SPSS 16.0 version for windows.

To assess the degree of ossification of the medial clavicular epiphyseal cartilage, the five stage system proposed by Schmeling et al., (2004) was applied as follows:

Stage 1: the ossification centre has not yet ossified Stage 2: the ossification centre has ossified; the epiphyseal cartilage has not ossified.

Stage 3: the epiphyseal cartilage is partially ossified.

Stage 4: the epiphyseal cartilage is fully ossified.

Stage 5: the epiphyseal cartilage has fused completely and the epiphyseal scar is no longer visible.
Table I. Age distribution of the stage of maturation of the left medial clavicular epiphysis in males.

\begin{tabular}{|c|c|c|c|c|c|c|}
\hline Age & Number & Stage 1 & Stage 2 & Stage 3 & Stage 4 & Stage 5 \\
\hline 16 & 4 & 3 & 1 & & & \\
\hline 17 & 13 & 6 & 7 & & & \\
\hline 18 & 40 & 7 & 32 & 1 & & \\
\hline 19 & 53 & 5 & 36 & 12 & & \\
\hline 20 & 38 & 1 & 29 & 8 & & \\
\hline 21 & 40 & & 24 & 14 & 2 & \\
\hline 22 & 34 & & 6 & 25 & 3 & \\
\hline 23 & 31 & & 2 & 20 & 9 & \\
\hline 24 & 32 & & 2 & 11 & 19 & \\
\hline 25 & 34 & & & 12 & 19 & 3 \\
\hline 26 & 33 & & & 7 & 22 & 4 \\
\hline 27 & 27 & & & 3 & 14 & 10 \\
\hline 28 & 28 & & & 4 & 13 & 11 \\
\hline 29 & 33 & & & 5 & 18 & 10 \\
\hline 30 & 30 & & & 1 & 17 & 12 \\
\hline 31 & 20 & & & 1 & 5 & 14 \\
\hline 32 & 16 & & & & 2 & 14 \\
\hline Total & 506 & 22 & 139 & 124 & 143 & 78 \\
\hline
\end{tabular}

ND**-no data available, at the time of study stage 5 had not yet been described by Schmeling(2004). ND***-no data available, subsample was too small.

\section{RESULTS}

X-rays from 588 males and 447 females were studied. In $4.6 \%$ of the $\mathrm{x}$-rays there was a maturity gap between the stages of the right clavicle and the left clavicle. This however did not produce any statistical significance between the left and right clavicle for any given stage, therefore only the results of the left clavicle was used.

Statistically significant differences were produced at stages 2 , 3 and $4(\mathrm{p}=0.001$ for stages 2 and 4 , and $\mathrm{p}<0.001$ for stage 3 ) when sex comparisons were made, there was no statistical disparity for stage 5 $(\mathrm{p}=0.66)$. No statistical parameters were calculated for stage 1 because of the small subsample, as the age distribution of the population from which the sample was taken excluded a lot of the ages in which stage 1 was most likely to be detected. 
BROWN A. A.; DERKYI-KWARTENG L. \& AMONOO-KUOFI H. S. Study on the time frame for ossification of the medial clavicular epiphyseal cartilage by X-ray in Ghanaian students. Int. J. Morphol., 31(2):491-496, 2013

Table II. Age distribution of the stage of maturation of the left medial clavicular epiphysis in females.

\begin{tabular}{|c|c|c|c|c|c|c|}
\hline Age & Number & Stage 1 & Stage 2 & S tage 3 & Stage 4 & Stage 5 \\
\hline 16 & 3 & 2 & 1 & & & \\
\hline 17 & 15 & 4 & 10 & 1 & & \\
\hline 18 & 38 & 3 & 32 & 3 & & \\
\hline 19 & 55 & 1 & 32 & 22 & & \\
\hline 20 & 43 & & 19 & 22 & 2 & \\
\hline 21 & 21 & & 7 & 12 & 2 & \\
\hline 22 & 23 & & 3 & 14 & 6 & \\
\hline 23 & 24 & & & 9 & 15 & \\
\hline 24 & 30 & & & 10 & 20 & \\
\hline 25 & 25 & & & 8 & 16 & 1 \\
\hline 26 & 32 & & & 3 & 22 & 7 \\
\hline 27 & 24 & & & 3 & 7 & 14 \\
\hline 28 & 18 & & & 2 & 8 & 8 \\
\hline 29 & 15 & & & 1 & 6 & 8 \\
\hline 30 & 26 & & & 1 & 10 & 15 \\
\hline 31 & 16 & & & & 3 & 13 \\
\hline 32 & 11 & & & & 1 & 10 \\
\hline Total & 419 & 10 & 104 & 111 & 118 & 76 \\
\hline
\end{tabular}

Table III. Statistical parameters by sex for ossification stages 2-5 of left clavicle.

\begin{tabular}{clccc}
\hline Stage & Sex & Min-Max & Mean \pm SD & $p$-value \\
\hline 2 & Male & $16-24$ & $19.46 \pm 1.476$ & 0.001 \\
& Female & $16-22$ & $18.88 \pm 1.220$ & \\
3 & Male & $18-31$ & $23.02 \pm 2.754$ & $<$ \\
& Female & $17-30$ & $21.71 \pm 2.681$ & 0.001 \\
4 & Male & $21-32$ & $26.65 \pm 2.532$ & 0.001 \\
& Female & $20-32$ & $25.62 \pm 2.608$ & \\
5 & Male & $25-32$ & $29.35 \pm 2.037$ & 0.510 \\
& Female & $25-32$ & $29.13 \pm 1.996$ & \\
\hline
\end{tabular}

P-values testing for significant statistical differences between the mean ages of male and female.

The minimal age at which stage 2 occurred was 16 years for both sexes which coincides with the lower age limit of this study. This most likely indicates that if the sample was to be taken from a population with a wider age distribution, the minimal age for stage 2 could have been much lower.

Partial union (stage 3) was found from ages 17 in females and 18 in males until ages 30 and 31 in females and males respectively. Complete union (stage 4) was first
Table IV. Statistical parameters for ossification stages 2-5 for left and right clavicles.

\begin{tabular}{llccc}
\hline Stage & Sex & Side & Mean \pm SD & $p$-value \\
\hline 2 & Male & Left & $19.46 \pm 1.476$ & 0.813 \\
& & Right & $19.50 \pm 1.562$ & \\
& Female & Left & $18.88 \pm 1.220$ & 0.818 \\
& & Right & $18.84 \pm 1.231$ & \\
3 & Male & Left & $23.02 \pm 2.754$ & 0.682 \\
& & Right & $22.89 \pm 2.639$ & \\
& Female & Left & $21.71 \pm 2.681$ & 0.424 \\
& & Right & $21.43 \pm 2.51$ & \\
4 & Male & Left & $26.65 \pm 2.532$ & 0.955 \\
& & Right & $26.63 \pm 2.571$ & \\
& Female & Left & $25.62 \pm 2.608$ & 0.515 \\
& & Right & $25.84 \pm 2.636$ & \\
5 & Male & Left & $29.35 \pm 2.037$ & 0.842 \\
& & Right & $29.41 \pm 1.983$ & \\
& Female & Left & $29.13 \pm 1.996$ & 0.905 \\
& & Right & $29.09 \pm 2.060$ & \\
\hline
\end{tabular}

P-values testing for significant statistical differences between the mean ages of the left and right clavicles

observed at age 20 years in females and 21 years in males, and with $100 \%$ of the sample achieving complete union at ages 30 and 31 years in females and males respectively. 
BROWN A. A.; DERKYI-KWARTENG L. \& AMONOO-KUOFI H. S. Study on the time frame for ossification of the medial clavicular epiphyseal cartilage by X-ray in Ghanaian students. Int. J. Morphol., 31(2):491-496, 2013.

Table V. Some recent studies dealing with ossification of the medial clavicle.

\begin{tabular}{lccccccc}
\hline Author & Sample & $\begin{array}{c}\text { Age } \\
\text { (years) }\end{array}$ & Meth od & $\begin{array}{c}\text { Stage 2(age } \\
\text { in years) }\end{array}$ & $\begin{array}{c}\text { Stage 3 (age } \\
\text { in years) }\end{array}$ & $\begin{array}{c}\text { Stage 4 (age } \\
\text { in years) }\end{array}$ & $\begin{array}{c}\text { Stage 5 (age } \\
\text { in years) }\end{array}$ \\
\hline Webb \& Suchey (1985) & 859 & $11-40$ & Skeletal Observation & $16-22$ & $16-33$ & $20-40$ & ND* \\
Kreitner (1998) & 380 & $0-29$ & CT Images & $11-22$ & $16-26$ & $22-29$ & ND** \\
Schmeling (2004) & 873 & $16-30$ & X-ray Images & ND*** & $16-26$ & $20-30$ & $26-30$ \\
Schulz (2005) & 629 & $15-30$ & CT Images & $15-23$ & $16-28$ & $21-30$ & $21-30$ \\
Kellinghaus (2010) & 592 & $10-35$ & CT Images & $13-20$ & $16-26$ & $21-35$ & $26-35$ \\
Present Study & 1035 & $16-32$ & X-ray Images & $16-24$ & $17-31$ & $20-32$ & $25-32$ \\
\hline
\end{tabular}

ND*-no data available, stage 5 applies to radiological assessment not direct skeletal observation.

\section{DISCUSSION}

Comparing the results from this study to those that have been already conducted has shown some significant differences. Evidence from published reports suggests that the time frame for the appearance of the secondary ossification centres (stage 2) in most of the studied subjects ranges from 11 to 13 years. In the present study it was found to be 16 years. The lower age limit in this study was 16 year so this result can not be used to make any firm conclusion. The maximum age for stage 2 was found to be 22 in females and this falls within the range of some of the recent radiological studies (Kreitner et al., 1998, Schulz et al., 2005). The maximum age for males at this stage was 24 years.

The onset of the partial fusion was noted at 17 years in females and 18 years in males. This varied from the time of onset reported by Schmeling et al., (2004), who reported an onset age of 16 years for both males and females. This stage also lasted much longer than in other radiological studies (Flecker, 1933; Jit \& Kullkarni, 1976, Kreitner et al., 1998, Schmeling et al., 2004, Schulz et al., 2005, Kellinghaus et al., 2010) though it concurred with results generated from anatomical studies (McKern \& Stewart, 1957; Webb \& Suchey, 1985). Kreitner et al., (1998) speculated that these delays that were observed in direct inspection of the human skeleton were due to methodological problems; where persistent small grooves or notches that were directly observed may have been recorded as partial fusion. In the present study the medial clavicle was assessed radiologically and not by direct observation therefore this hypothesis could not apply.

The minimal age at which complete ossification (stage 4) occurred was observed to be 20 years in females and 21 years in males. This also fell within result reported by recent studies and is identical with the values of Schmeling et al., (2004) who also conducted his study on conventional $x$-ray. The maximum age at which this stage occurred in our study was 31 and 32 years in females and males respectively, Stage 5 occurred at age 25 for both male and females.

Apart from stage 5, all the stages showed significant statistical differences in their mean ages when sex comparison were made. Female development appeared to precede male development and this was in agreement with the findings of Meijerman et al., (2007), who noted a general earlier onset of the fusion of the medial clavicular epiphysis in females than in males. This observation has also been reported for the epiphyseal fusion of long bones other than the clavicle (Patel et al., 2009 \& Patterson, 1929).

In our study $4.6 \%$ of the $\mathrm{X}$-rays showed a developmental gap between the left and right clavicle. However there was no statistical significant difference when the mean values of the right and left clavicle were compared for each stage. It seems reasonable therefore to conclude that results from either left or right clavicle can be used during the forensic estimation of age. As with other studies, the superimposition of other structures over the medial clavicle made it difficult for it to be always visible.

The effect of socio economic level of subjects on the rate of ossification has been well documented by Schmeling et al., 2006 and Meijerman et al., 2007. Both papers found that subjects from lower economic condition tend to have delayed fusion of their epiphyses as compared to subject from higher socio-economic conditions. This could account for the longer duration of stage 3 as compared to other studies which have been conducted in areas of greater socioeconomic advancement.

Poor nutrition which is related to low socio-economic status has been shown to generally retard linear growth (Ulijaszek et al., 2006) and may also contribute to the delayed fusion observed in stage 3 . 
Malaria infection which is endemic in this environment may also contribute to the delay noticed in stage 3. Chronic exposure to Tumour Necrotic Factor alpha (TNF-a ) a pro-inflammatory cytokine as a result of repeated malaria infection may contribute to the delayed growth (Friedman et al., 2003) especially as chronic elevations of TNF-a may directly inhibits new bone formation at epiphyseal plate. (De Luca, 2006; WalkerSmith, 1996).

\section{CONCLUSION}

Evidence from the present study appears to support the fact that conventional x-ray of the medial clavicle can be an effective tool in assessing forensic age of subjects for any purpose. This method may also be very useful in sub
Saharan Africa especially in locations where only x-ray imaging may be available to assess the age of living subjects. There is however a need to develop reference values that are specific for particular geographical areas so that forensic estimation of age will be more accurate.

\section{ACKNOWLEDGEMENTS}

The authors thank Prof. Nana K. Ayisi of the Department of Pharmacology, School of Medical Sciences University of Cape Coast, for reviewing this manuscript and making valuable corrections and suggestions.

Special thanks to the Director, radiographers and $\mathrm{x}$ ray technicians of the University of Cape Coast Hospital for making available the $\mathrm{x}$-rays used for this project.

BROWN A. A.; DERKYI-KWARTENG L. \& AMONOO-KUOFI H. S. Estudio con rayos X sobre el periodo de tiempo de la osificación de la epífisis medial del cartílago clavicular en los estudiantes ghaneses. Int. J. Morphol., 31(2):491-496, 2013.

RESUMEN: El objetivo de este estudio fue determinar la tasa de osificación de la extremidad esternal de la clavícula y determinar algunos de los diferentes factores que pueden influir en la tasa de osificación en la población de Ghana. Se efectuó un estudio retrospectivo en el hospital de la Universidad de Cape Coast, Cape Coast, Ghana. Se utilizaron 1035 radiografías de tórax de estudiantes admitidos al primer año de la Universidad de Cape Coast, el año académico 2008/2009. Se observaron diferencias estadísticamente significativas para algunas de las etapas en que se realizan comparaciones de sexo mediante el t-test para dos grupos independientes con un nivel de confianza del 95\%. Etapas $2(\mathrm{p}=0,001)$, la etapa $3(\mathrm{p}<0,001)$ y la etapa $4(\mathrm{p}=0-001)$. La edad de inicio de la osificación de la extremidad esternal de la clavícula aparecía generalmente antes en las mujeres que en los hombres. La etapa de osificación parcial de las extremidad esternal de la clavícula también duró más tiempo que lo relatado en otros estudios los cuales indican un retraso en la osificación en esta etapa. En conclusión la radiografía convencional de la extremidad esternal de la clavícula puede ser una herramienta eficaz en la evaluación forense de la edad de los sujetos, sin embargo existe necesidad de definir valores de referencia que sean específicos para determinadas zonas geográficas.

\section{PALABRAS CLAVE: Clavícula; Anatomía; Osificación.}

\section{REFERENCES}

Black, S. M. \& Scheuer, J. L. Age changes in the clavicle: from the early neonatal period to skeletal maturity. Int. J. Osteoarchaeol., 6:425-34, 1996.

De Luca, F. Impaired Growth Plate Chondrogenesis in Children with Chronic Illnesses. Pediatric Research, 59:625-9, 2006.

Flecker, H. Roentgenographic observations of the times of appearance of epiphyses and their fusion with the diaphyses. J Anat 67:118-64, 1933.

Friedman, J. F.; Kurtis, J. D.; Mtalib, R.; Opollo, M.; Lanar, D. E. \& Duffy, P. E. Malaria is related to decreased nutritional status among male adolescents and adults in the setting of intense perennial transmission. J. Infect. Dis., 188:449-57, 2003.
Ji, L.; Terazawa, K.; Tsukamoto, T. \& Haga, K. Estimation of age rom epiphyseal union degrees of the sternal end of the clavicle. Hokkaido Igaku Zasshi, 69:104-11,1994.

Jit, I. \& Kulkarni, M. Times of appearance and fusion of epiphysis at the medial end of the clavicle. Indian J. Med. Res., 64:77382,1976

Kellinghaus, M.; Schulz, R.; Vieth, V.; Schmidt, S. \& Schmeling, A. Forensic age estimation in living subjects based on the ossification status of the medial clavicular epiphysis as revealed by thin-slice multidetector computed tomography. Int. J. Legal Med., 124:149-54, 2010.

Kreitner, K. F.; Schweden, F.; Riepert, T.; Nafe, B. \& Thelen, M. Bone age determination based on the study of the medial extremity of the clavicle. Eur. Radiol., 8:1116-22, 1998. 
BROWN A. A.; DERKYI-KWARTENG L. \& AMONOO-KUOFI H. S. Study on the time frame for ossification of the medial clavicular epiphyseal cartilage by X-ray in Ghanaian students. Int. J. Morphol., 31(2):491-496, 2013.

McKern, T. W. \& Stewart, T. D. Skeletal age changes in young American males. Analysed from the standpoint of age identification. In: Technical report EP-45. Quartermaster Research and Development Center, Environmental Protection Research Division, Natick, Mass., 1957. pp 89-97.

Meijerman, L.; Maat, G.; Schulz, R. \& Schmeling, A. Variables affecting the probability of complete fusion of the medial clavicular epiphysis. Int. J. Legal Med., 121:463-8, 2007.

Patel, B.; Reed, M. \& Patel, S. Gender-specific pattern differences of the ossification centers in the pediatric elbow. Pediatr. Radiol., 39:226-31, 2009.

Patterson, R. S. A radiological investigation of the epiphyses of the long bones. J. Anat., 64:29-46, 1929.

Schmeling, A.; Olze, A.; Reisinger, W. \& Geserick, G. Age estimation of living people undergoing criminal proceedings. Lancet, 358:89-90, 2001.

Schmeling, A.; Reisinger, W.; Loreck, D.; Vendura, K.; Markus, W. \& Geserick, G. Effects of ethnicity on skeletal maturation: consequences for forensic age estimations. Int. J. Legal Med., 113:253-8, 2000.

Schmeling, A.; Schulz, R.; Danner, B. \& Rosing, F. W. The impact of economic progress and modernization in medicine on the ossification of hand and wrist. Int. J. Legal Med., 120:121-6, 2006.

Schmeling, A.; Schulz, R.; Reisinger, W.; Mühler, M.; Wernecke, K. \& Geserick, G. Studies on the time frame for ossification of the medial clavicular epiphyseal cartilage in conventional radiography. Int. J. Legal Med., 118:5-8, 2004.

Schulz, R.; Mühler, M.; Mutze, S.; Schmidt, S.; Reisinger W. \& Schmeling, A. Studies on the time frame for ossification of the medial epiphysis of the clavicle as revealed by CT-scans. Int. J. Legal Med., 119:142-5, 2005.

Todd, T. W. \& D'Errico, J. The clavicular epiphyses. Am. J. Anat., 41:25-50,1928.

Ulijaszek, S. J. The International Growth Standard for Children and Adolescents Project: Environmental influences on preadolescent and adolescent growth in weight and height. Food and Nutrition Bulletin, 27:279-94, 2006.

Walker-Smith, J. A. Management of growth failure in Crohn's disease. Arch. Dis. Child., 75:351-4, 1996.

Webb, O. P. A. \& Suchey, M. J. Epiphyseal union of the anterior iliac crest and medial clavicle in a modern multi-racial sample of American males and females. Am. J. Phys. Anthropol., 68:457-66, 1985.

\section{Correspondence to: \\ Dr. Brown A. A. \\ Department of Anatomy \\ School of Medical Sciences \\ University of Cape Coast \\ GHANA}

Email: ampomahbrown@yahoo.com

Received: 25-09-2012

Accepted: 04-02-2013 